\title{
The genus Hyalomma Koch, 1844. III. Redescription of the adults and larva of $H$. (Euhyalomma) impressum Koch, 1844 (Acari: Ixodidae) with a first description of its nymph and notes on its biology
}

\author{
Dmitry A. Apanaskevich ${ }^{1}$ and Ivan G. Horak ${ }^{2}$ \\ ${ }^{1}$ United States National Tick Collection, Institute of Arthropodology and Parasitology, Georgia Southern University, Statesboro, \\ GA 30460-8056, USA; \\ ${ }^{2}$ Department of Veterinary Tropical Diseases, Faculty of Veterinary Science, University of Pretoria, Onderstepoort, 0110, South \\ Africa, and Division of Parasitology, Onderstepoort Veterinary Institute, Onderstepoort, 0110, South Africa
}

Key words: Hyalomma (Euhyalomma) impressum, systematics, male, female, nymph, larva, distribution, hosts

\begin{abstract}
In respect of its morphology, biology and epidemiology, Hyalomma (Euhyalomma) impressum Koch, 1844 is one of the more poorly studied ticks of the genus Hyalomma Koch, 1844. No comprehensive morphological study has been done to date, and the nymph has not been described. Here the adults and larva are redescribed, and the nymph is described for the first time. Data on hosts, geographical distribution and disease relationships are provided.
\end{abstract}

Hyalomma (Euhyalomma) impressum Koch, 1844 was originally described as an independent species (Koch 1844). However, Neumann (1901) considered it to be a variety of the catchall species Hyalomma aegyptium (Linnaeus, 1758). Schulze (1919) and Schulze and Schlottke (1930) recognized $H$. impressum as a polytypic species and included Hyalomma truncatum Koch, 1844, Hyalomma marginatum rufipes Koch, 1844, and other synonymous names as subspecies or forms. The subsequent works on the adults of $H$. impressum by Delpy (1949), Feldman-Muhsam (1954) and Hoogstraal (1956) more precisely defined its specific status.

Despite the presence of quite distinct characters in the male, making it easily recognizable from other $\mathrm{Hya}$ lomma species, there are still some difficulties associated with the identification of adults. For instance, $H$. impressum adults are often mistaken for those of $H . \mathrm{m}$. rufipes. Adults of the latter tick also have a punctate scutum and conscutum and there has been a tendency to mistake $H$. impressum for $H$. $m$. rufipes, or combine the two. This led Russian ixodologists, who followed the suggestions of Pomerantsev (1946, 1950), to consider $H$. $m$. rufipes collected in the former USSR as being Hyalomma marginatum impressum Pomerantsev, 1946 or Hyalomma plumbeum impressum Pomerantsev, 1946. The adults of $H$. impressum sometimes also resemble those of heavily punctate $H$. truncatum. Specific identification of the immature stages has been impossible to date.

The aim of this study is to redescribe the adults and larva of $H$. impressum and to describe the nymph for the first time. This should assist parasitologists and epidemiologists in their studies on the biology and medicoveterinary importance of this poorly known Hyalomma species.

\section{MATERIALS AND METHODS}

A total of 137 males, 22 females, 5 nymphs, and 35 larvae that originated from Egypt, Central African Republic, Mali, Nigeria, Senegal and Sudan were examined in the current study. Both field-collected and laboratory-reared specimens were studied. The type specimen has also been examined by the senior author (DAA). The specimens that were examined are housed in the United States National Tick Collection (Institute of Arthropodology and Parasitology, Georgia Southern University, Statesboro, USA), the Zoological Institute of the Russian Academy of Sciences (St. Petersburg, Russia), the Natural History Museum of Berlin (Berlin, Germany), the Gertrud Theiler Tick Museum at the Onderstepoort Veterinary Institute (Onderstepoort, South Africa) and in the personal tick collection of Dr. J.B. Walker (South Africa).

The immature stages and the finer structures of the adults were mounted on glass slides and examined under a light microscope, and the macrostructures of males and females under a stereoscopic microscope. The spiracular plate of the nymph was studied using a scanning electron microscope. Measurements for the male conscutum and female scutum are given in millimetres $(\mathrm{mm})$, and those for the immature stages in micrometres $(\mu \mathrm{m})$. The measurements are arranged as follows: minimum-maximum (average \pm standard deviation, $\mathrm{n}=$ number of specimens measured), and their schematic layout is to be found in Apanaskevich (2003), and Apanaskevich and Horak (2006).

\section{RESULTS}

Hyalomma (Euhyalomma) impressum Koch, 1844

Figs. 1-7

Type specimens: the original description was based on specimens (ð゚) from Senegal (“Senegal”, p. 221, Koch 1844). The type specimen (1ڤ̂, Senegal, leg.

Address for correspondence: D.A. Apanaskevich, United States National Tick Collection, Institute of Arthropodology and Parasitology, Georgia Southern University, P.O. Box 8056, Statesboro, GA 30460-8056, USA. Phone: ++1 912 681 5564; Fax: ++1 912 681 0559;

E-mail: dapanaskevich@georgiasouthern.edu 
Mion, Type, ZMB 1071) is deposited in the Natural History Museum of Berlin (Berlin, Germany).

Synonyms (Camicas et al. 1998 with corrections):

Hyalomma aegyptium var. impressum Koch, 1844 sensu Neumann 1901;

Hyalomma aegyptium impressum Koch, 1844 sensu Neumann 1911;

Hyalomma aegyptium impressum f. typica Schulze, 1919;

Hyalomma impressum impressum Koch, 1844 sensu Schulze and Schlottke 1930;

Hyalomma dromedarii impressa Koch, 1844 sensu Neveu-Lemaire 1938;

Hyalomma savignyi intermedia Rousselot, 1946;

Hyalomma dromedarii impressum Koch, 1844 sensu

Curasson 1947

Descriptions and illustrations of adults are available in a number of publications and we consider the most useful of these to be found in Feldman-Muhsam (1954) and Hoogstraal (1956). The larva is illustrated and described in Camicas (1970). The nymph has never been described.

\section{Description}

Male

Figs. 1, 2A-H, 3A

Conscutum (Fig. 1): length 3.26-4.30 (3.83 $\pm 0.21, \mathrm{n}$ $=119)$, width $2.02-2.70(2.34 \pm 0.13, \mathrm{n}=119)$, ratio length:width $1.48-1.77(1.64 \pm 0.05, \mathrm{n}=119)$; dark redbrown in colour; pale marbling absent; narrowly oval in shape; widest near mid-length; pronounced narrowing in region of spiracular plates; cervical and lateral grooves superficial, up to $1 / 3$ length of conscutum; marginal grooves short, furrow-like, extending to posterior $1 / 3$ of conscutum, however, dense and deep punctations aligned with marginal groove give it appearance of a long but shallow groove almost 2/3's of conscutum length; posteromedian and paramedian grooves poorly defined, obscured by dense punctations; caudal field poorly defined; medium-sized punctations fairly evenly dispersed over conscutum, more dense, often contiguous on caudal field, less dense on elevations demarcating this field; parma absent; 5 distinct festoons. Genital structures (Fig. 2A) as illustrated. Anal shields (Fig. 2B): 3 pairs; adanal plates long, broad, tapering slightly posterior to median projection, lateral margin slightly convex, anteriomedian margin concave, median projection fairly distinct, posteriomedian margin straight; subanal plates variable both in size and shape, usually small, rounded and longitudinally aligned. Ventral sclerotized plaque absent on median but present on paramedian festoons. Spiracular plate (Fig. 2C): dorsal prolongation long and clearly distinct from body of plate; perforated portion of prolongation straight, curving at its apex, relatively broad. Circumspiracular setae sparse.

Basis capituli (Fig. 2D, E): without lateral projections; dorsal posterior margin slightly concave or straight; cornua moderate. Palpi (Fig. 2F): segment I

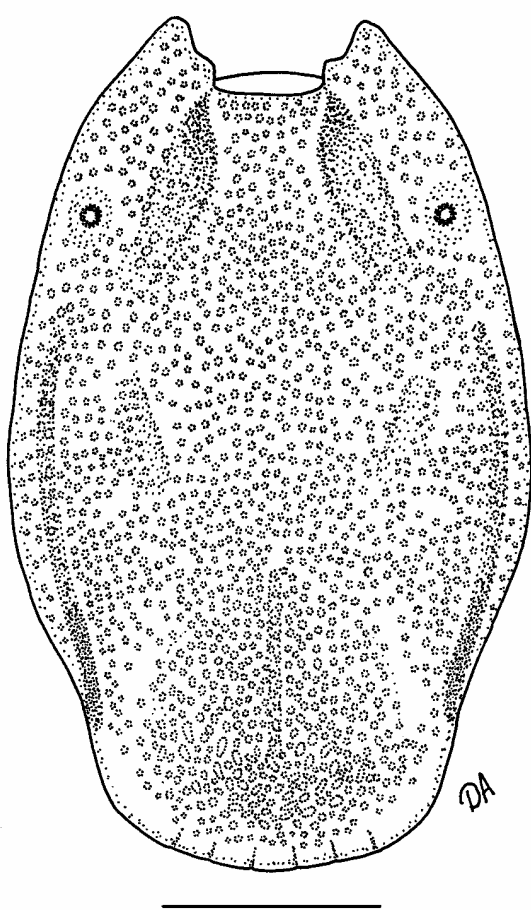

Fig. 1. Hyalomma impressum, male, conscutum. Scale bar $=1$ $\mathrm{mm}$.

with more than 5 ventromedian setae. Hypostome (Fig. $2 \mathrm{G})$ : club-shaped; denticulate portion slightly longer than denticle-free portion (small scale-like projections posterior to last large denticle are not considered denticles).

Coxae (Fig. 2H): posteromedian and posterolateral spurs of coxae I long, close together, tapering to apices; coxae II-IV each with distinct, triangular, posterolateral spur with rounded apex; coxae II and III each with poorly developed, broadly arcuate, posteromedian spur; internal spur on coxa IV distinct, triangular. Ivorycoloured enamel band encircles distal portion of each segment of the legs (Fig. 3A).

Female

Figs. 3B, 4, 5A-G

Scutum (Fig. 4): length 1.97-2.42 (2.20 $\pm 0.12, \mathrm{n}=$ 16), width 1.99-2.45 $(2.19 \pm 0.13, \mathrm{n}=16)$, ratio length: width $0.97-1.06(1.01 \pm 0.03, \mathrm{n}=16)$; dark red-brown to nearly black in colour; pale marbling absent; nearly as long as broad; posterolateral angles slight; cervical and lateral grooves moderately deep, extending to posterior margin of scutum; medium-sized punctations dense, deep, uniformly covering scutum. Genital structures (Fig. 5A): genital aperture relatively narrow, deep, rounded (U-shaped); vestibular portion of vagina bulging. Spiracular plates (Fig. 5B): perforated portion of dorsal prolongation curved and relatively broad. Circumspiracular setae sparse.

Basis capituli (Fig. 5C, D): dorsally lateral projections short, absent ventrally; dorsal posterior margin straight; dorsal cornua inconspicuous. Palpi (Fig. 5E): 


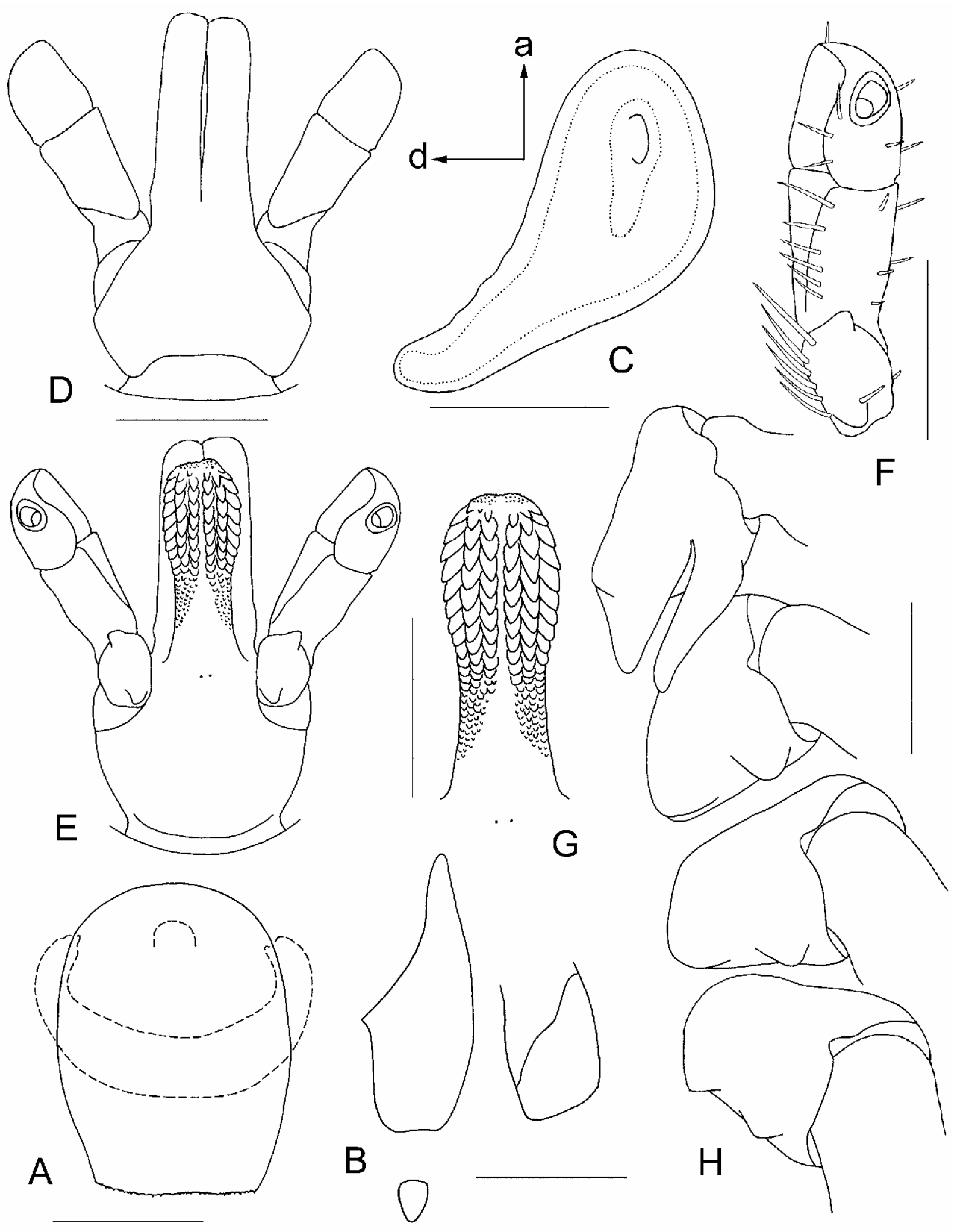

Fig. 2. Hyalomma impressum, male. A - genital structures; B - anal plates; C - spiracular plate (a - anterior, d - dorsal); D gnathosoma dorsally; $\mathbf{E}$ - gnathosoma ventrally; $\mathbf{F}$ - palp ventrally; $\mathbf{G}$ - hypostome; $\mathbf{H}$ - coxae. All setation is omitted except drawing F where only setae of segment IV are omitted. Scale bars: A = $200 \mu \mathrm{m} ; \mathrm{B}, \mathrm{D}, \mathrm{E}, \mathrm{H}=500 \mu \mathrm{m} ; \mathrm{C}, \mathrm{F}, \mathrm{G}=400 \mu \mathrm{m}$.

segment I with more than 5 ventromedian setae. $H y$ postome (Fig. 5F): club-shaped; denticulate portion slightly longer than denticle-free portion.

Coxae (Fig. 5G): posteromedian and posterolateral spurs of coxa I long, tapering to apices, close together; coxae II-IV each with distinct, broadly triangular posterolateral spur, with rounded apex; coxae II-IV each with poorly developed, broadly arcuate, posteromedian spur. Colouration of legs similar to that of male (Fig. 3B).

\section{Nymph}

Fig. $6 \mathrm{~A}-\mathrm{F}$

Scutum (Fig. 6A): length 615-634 $(625 \pm 13.80, \mathrm{n}=$ $2)$, width $683-693(688 \pm 6.90, \mathrm{n}=2)$, ratio length: width $0.89-0.93(0.91 \pm 0.03, \mathrm{n}=2)$, distance between posterior margin of eyes and posterior margin of scutum 224-234 $(229 \pm 6.90, \mathrm{n}=2)$, ratio width:length of posterior portion of scutum 2.92-3.09 $(3.00 \pm 0.12, \mathrm{n}=2)$; posterior margin of scutum very narrowly rounded; posterolateral depressions on either side of scutal apex almost invisible. Setae of alloscutum (Fig. 6B): without 

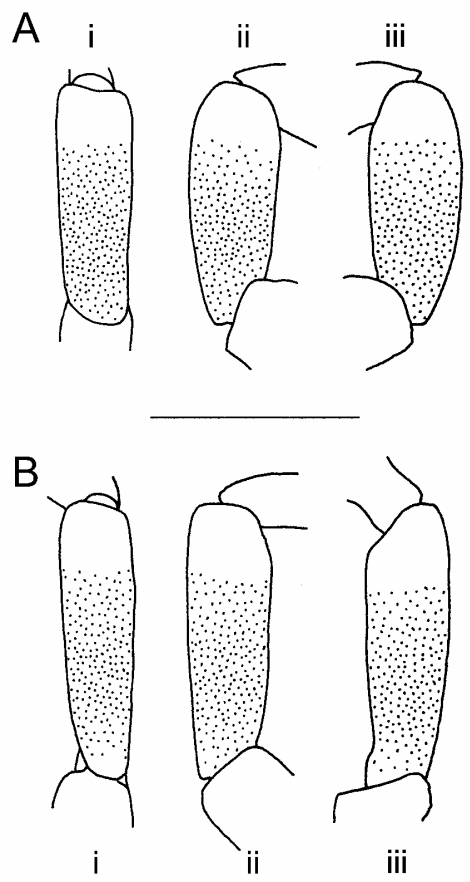

Fig. 3. Hyalomma impressum, genu IV. A - male: $\mathrm{i}$ - dorsal view, ii - lateral view, iii - medial view; $\mathbf{B}$ - female: $\mathrm{i}$ - dorsal view, $\mathrm{ii}-$ lateral view, $\mathrm{iii}-$ medial view. Scale bar $=1 \mathrm{~mm}$.

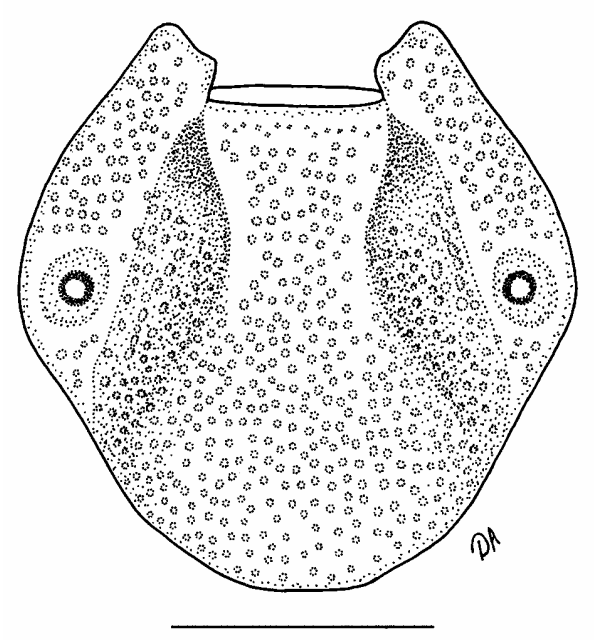

Fig. 4. Hyalomma impressum, female, scutum. Scale bar $=1$ $\mathrm{mm}$.

denticles, narrowing to rounded apex. Spiracular plates (Fig. 6C): oval; dorsal prolongation distinct, broad, blunt at apex; submarginal row of perforations complete.

Basis capituli (Fig. 6D, E): length 410-415 (412 \pm $3.53, \mathrm{n}=2)$; width $375(\mathrm{n}=2)$, ratio length:width $1.09-$ $1.11(1.10 \pm 0.01, \mathrm{n}=2$ ). Palpi (segment II) (Fig. 6D, E): length 199-202 $(200 \pm 1.70, \mathrm{n}=2)$, width 65-70 $(67$ $\pm 3.39, \mathrm{n}=2)$, ratio length:width $2.90-3.07(2.98 \pm$
$0.12, \mathrm{n}=2$ ); palpal segment II proximally narrow, gradually expanding distally. Hypostome (Fig. 6E): length 214-223 $(218 \pm 6.79, \mathrm{n}=2)$, width $82(\mathrm{n}=2)$, ratio length:width $2.62-2.73(2.68 \pm 0.08, \mathrm{n}=2)$; median file with 7 or 8 large denticles; transition of denticulate portion to denticle-free portion gradual; denticulate portion more than twice as long as denticle-free portion.

Coxae (Fig. 6F): coxa I with long, narrow, subtriangular spurs nearly equal in length; coxae II-IV each with moderate spur, spurs conspicuously decreasing in size from coxae II to IV; coxal pore present.

Larva

Fig. 7A-D

Scutum (Fig. 7A): length 217-245 $(233 \pm 5.44, \mathrm{n}=$ $34)$, width $330-370(344 \pm 9.07, \mathrm{n}=34)$, ratio length: width $0.59-0.71(0.68 \pm 0.02, \mathrm{n}=34)$, distance from posterior margin of eyes to posterior margin of scutum $50-62(57 \pm 3.47, \mathrm{n}=34)$, ratio width:length of posterior portion 5.28-6.80 $(6.03 \pm 0.39, \mathrm{n}=34)$. Portion of scutum posterior to eyes equal to $1 / 4$ of scutal length; posterior margin of scutum broadly rounded with distinct posterolateral depressions on either side of apex.

Basis capituli (Figs. 7B, C): 149-163 (155 \pm 3.43 , $\mathrm{n}=34$ ); subhexagonal dorsally; subtriangular ventrally; apex of dorsolateral projections directed slightly anteriorly; lateral projections distinct and appear acute from ventral view. Palpi (segments II and III) (Fig. 7B, C): length 98-108 $(103 \pm 2.20, \mathrm{n}=34)$, width 38-43 (40 \pm $0.87, \mathrm{n}=34)$, ratio length:width $2.41-2.67(2.55 \pm 0.06$, $\mathrm{n}=34)$. Hypostome (Fig. 7C): length $77-89(81 \pm 2.69$, $\mathrm{n}=34)$, width $24-28(25 \pm 0.90, \mathrm{n}=34)$, ratio length: width 3.00-3.50 $(3.19 \pm 0.12, \mathrm{n}=34)$; median file with 5 large denticles; transition of denticulate portion to denticle-free portion abrupt; denticulate portion approximately $1 / 2$ of hypostome length.

Coxae (Fig. 7D): coxa I with small, subtriangular spur, with rounded apex; coxae II-III each with small, fold-like, indistinct spur. Genua I: length 130-149 (140 $\pm 3.97, \mathrm{n}=34)$, width $43-48(47 \pm 1.49, \mathrm{n}=24)$, ratio length:width $2.70-3.22(3.00 \pm 0.11, \mathrm{n}=24)$.

\section{Related species}

The phylogenetic position of $H$. impressum is unclear. The narrowing of the conscutum at the level of the spiracular plates in the male places it close to the $H$. truncatum group of species. Because $H$. impressum shares parts of its distribution range with $H$. anatolicum Koch, 1844, H. dromedarii Koch, 1844, H. excavatum Koch, 1844, H. impeltatum Schulze et Schlottke, 1930, H. marginatum rufipes, H. nitidum Schulze, 1919 and $H$. truncatum, it is important to differentiate it from these ticks.

Males of $H$. impressum are distinguished from the other sympatric Hyalomma species by a combination of the following characters: prominent narrowing of the conscutum at the level of the spiracular plates, puncta- 


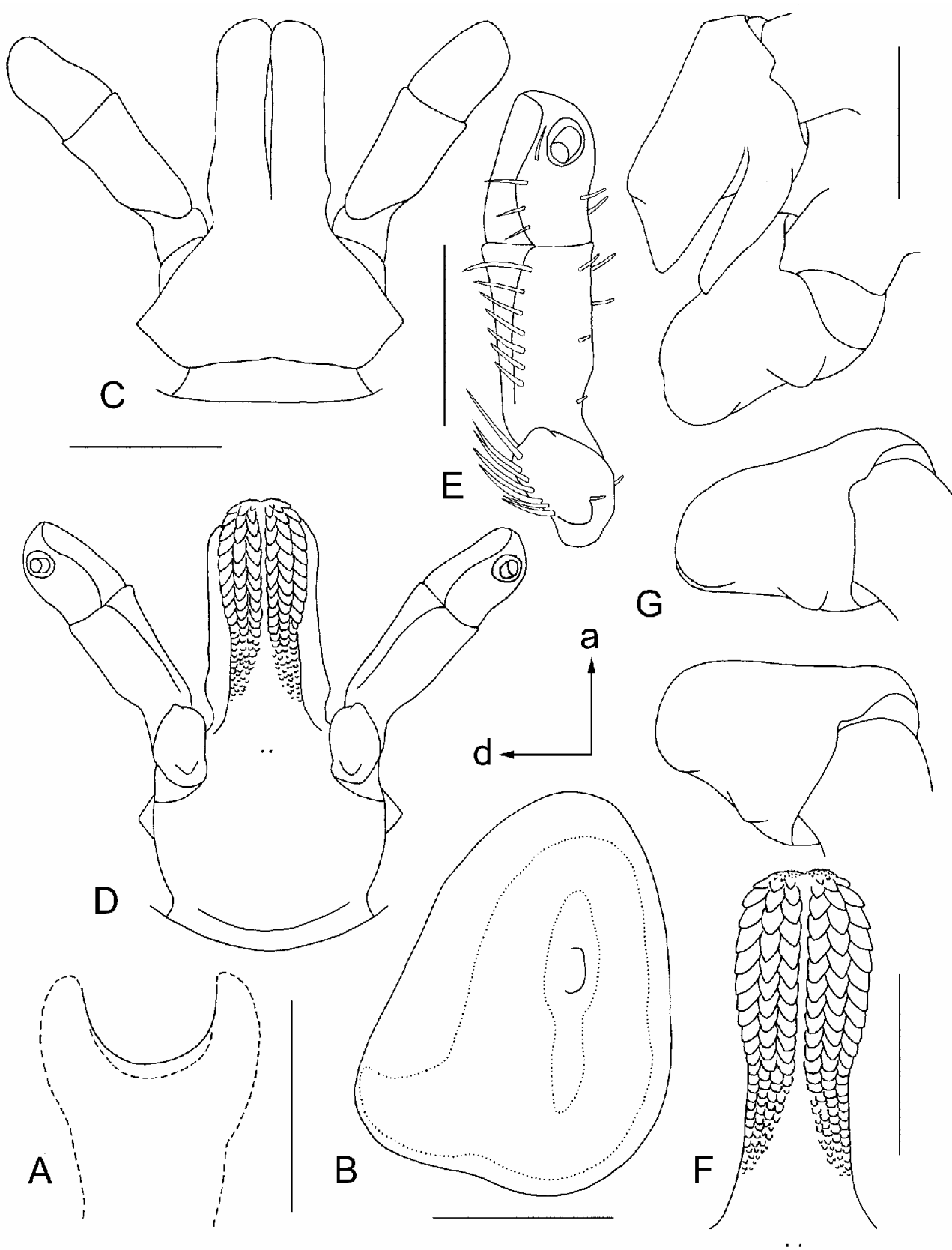

Fig. 5. Hyalomma impressum, female. A - genital structures; B - spiracular plate (a - anterior, d - dorsal); $\mathbf{C}$ - gnathosoma dorsally; D - gnathosoma ventrally; $\mathbf{E}$ - palp ventrally; $\mathbf{F}$ - hypostome; $\mathbf{G}$ - coxae. All setation is omitted except drawing E where only setae of segment IV are omitted. Scale bars: $A=200 \mu \mathrm{m} ; \mathrm{B}, \mathrm{E}, \mathrm{F}=400 \mu \mathrm{m} ; \mathrm{D}, \mathrm{C}, \mathrm{G}=500 \mu \mathrm{m}$.

tion of conscutum dense and deep, perforated portion of dorsal prolongation of spiracular plates relatively broad, circumspiracular setae sparse.

Females of $H$. impressum can be distinguished from the other sympatric Hyalomma species by a combination of the following characters: punctation of scutum dense and deep, genital operculum narrowly arcuate, vestibular part of vagina bulging, perforated portion of dorsal prolongation of spiracular plates relatively broad, circumspiracular setae sparse.

Superficially, the nymphs of $H$. impressum resemble those of $H$. truncatum and $H$. nitidum, but can easily be distinguished from them by the narrowly pointed posterior margin of the scutum with indistinct posterolateral depressions. Of the sympatric species only the nymphs of $H$. impeltatum have a similarly shaped scutum. The nymphs of $H$. impressum can be distinguished from those of $H$. impeltatum by their larger size and the proportions of various structures, such as scutum, gnathosoma, palpi and hypostome, a more denticulate hypostome and larger spurs on the coxae.

The shape and size of the posterior portion of the scutum of larvae of $H$. impressum are similar to those of $H$. anatolicum and $H$. excavatum in one respect and 


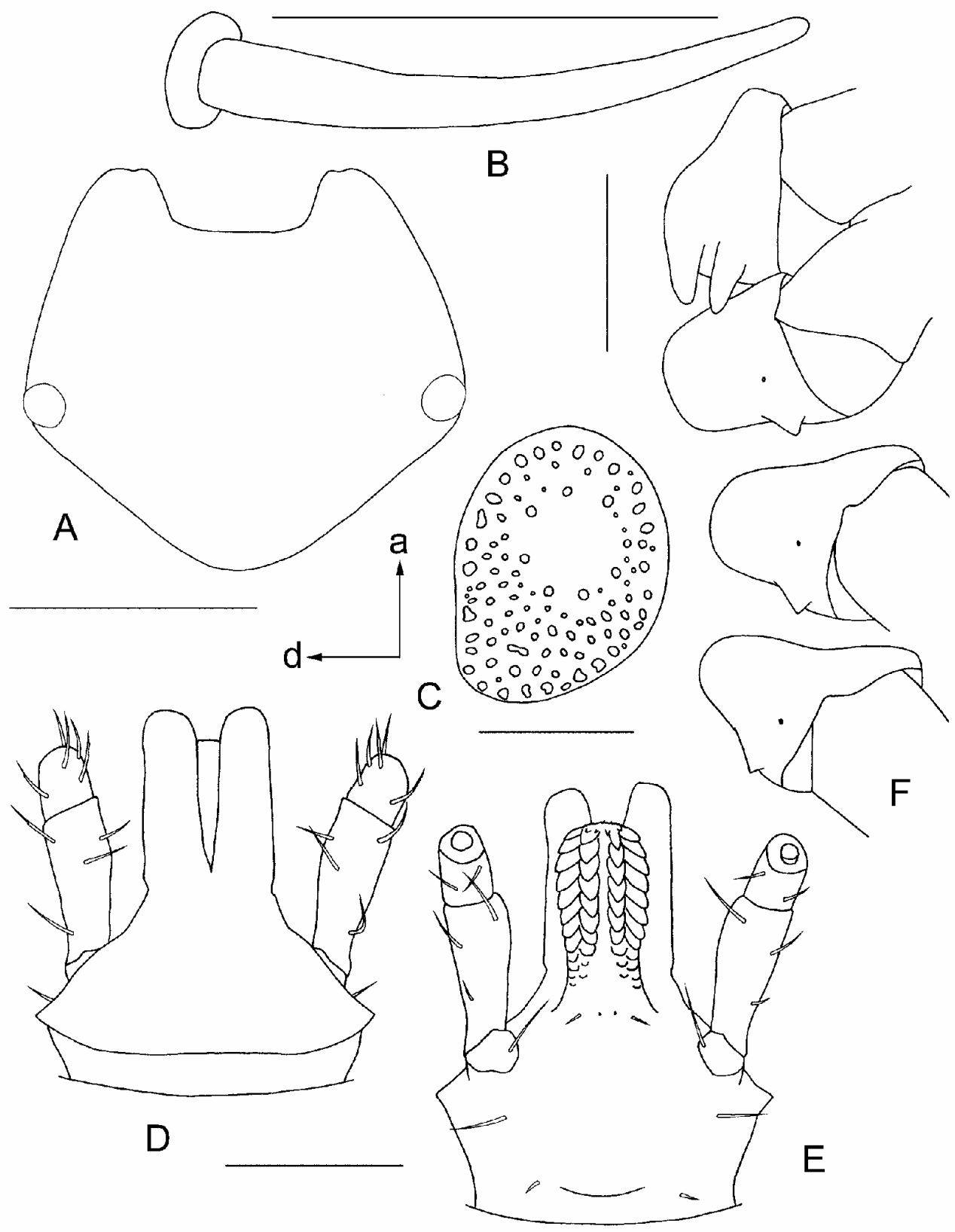

Fig. 6. Hyalomma impressum, nymph. A - scutum; B - setae of alloscutum; C - spiracular plate (a - anterior, d - dorsal); D gnathosoma dorsally; $\mathbf{E}$ - gnathosoma ventrally; $\mathbf{F}$ - coxae. All setation is omitted except drawings $\mathrm{D}$ and $\mathrm{E}$ where only setae of segment IV are omitted. Scale bars: $A=400 \mu \mathrm{m} ; \mathrm{B}, \mathrm{C}=50 \mu \mathrm{m} ; \mathrm{D}, \mathrm{E}, \mathrm{F}=200 \mu \mathrm{m}$.

to those of $H$. dromedarii and $H$. impeltatum in another. The larvae of $H$. impressum can be distinguished from those of other sympatric Hyalomma species by the small spur with rounded apex on coxa I and very small, foldlike spurs on coxae II and III.

\section{Hosts}

Hyalomma impressum is a three-host species (Centurier 1982). Adults have been collected from cattle, camels, sheep, horses, pigs and dogs (our data; Hoogstraal 1956, Morel 1958, Theiler 1962, Kolonin 1983). The only wild hosts recorded to date are warthogs, Phaco- choerus aethiopicus (Pallas) (Morel 1958). Two larvae have been found on Atelerix albiventris (Wagner) and Arvicanthis niloticus (Desmarest) (Camicas 1970).

\section{Zoogeography}

Known distribution of $H$. impressum is entirely confined to the Ethiopian zoogeographic region. Africa: Benin, Burkina Faso, Cameroon, Central African Republic, Chad, Democratic Republic of Congo, Ivory Coast, Mali, Niger, Nigeria, Senegal and Sudan (our data; Hoogstraal 1956, Morel 1958, Theiler 1962, Elbl and Anastos 1966, Kolonin 1983). Hoogstraal and Kai- 

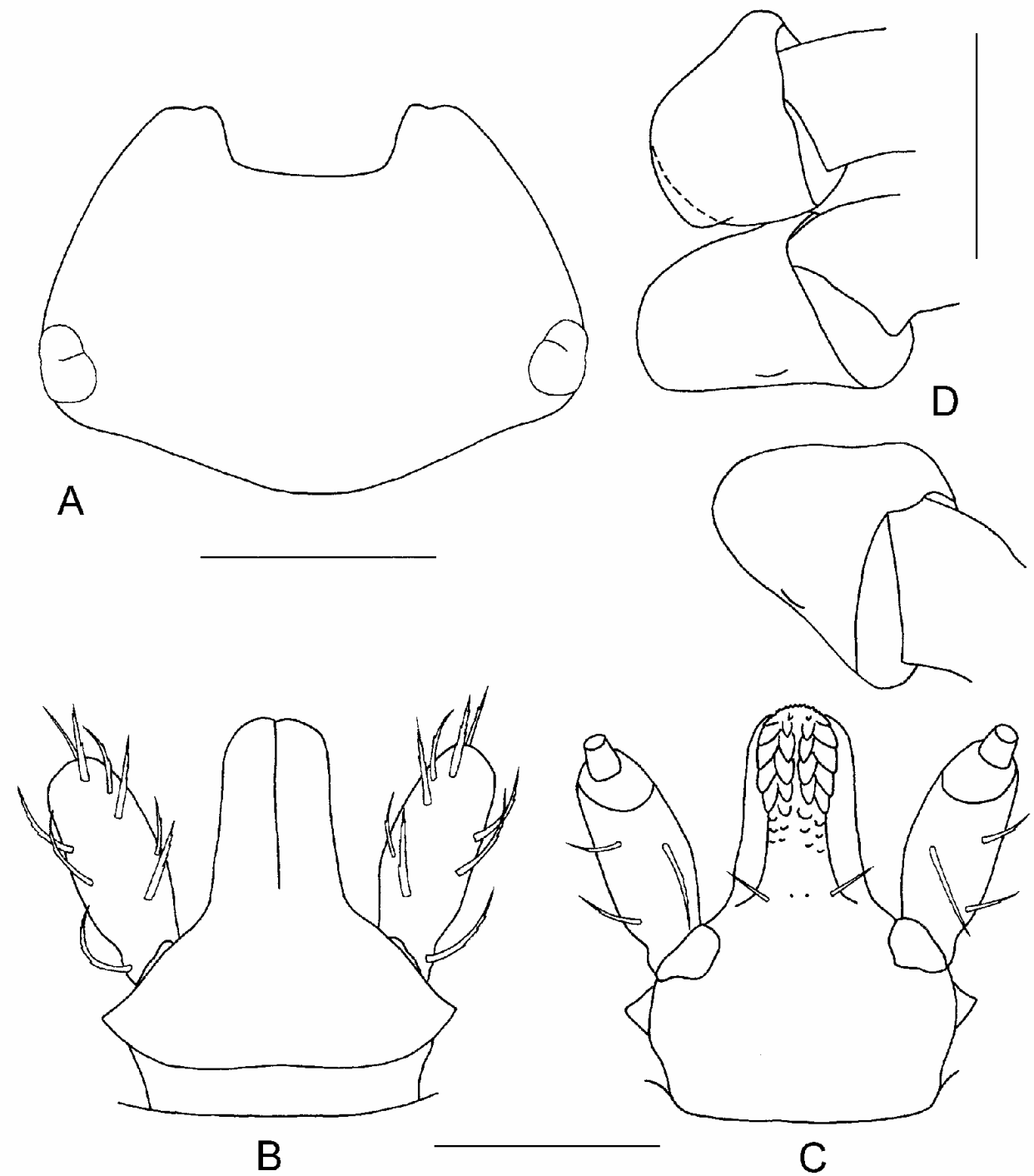

B

Fig. 7. Hyalomma impressum, larva. A - scutum; $\mathbf{B}$ - gnathosoma dorsally; $\mathbf{C}$ - gnathosoma ventrally; $\mathbf{D}$ - coxae. All setation is omitted except drawings B and C where only setae of segment IV are omitted. Scale bars: A $=150 \mu \mathrm{m} ; \mathrm{B}, \mathrm{C}, \mathrm{D}=100 \mu \mathrm{m}$.

ser (1958) recorded $H$. impressum from Egypt, but stated that it was of introduced origin. The record of $H$. impressum from Eritrea (Tonelli Rondelli 1930) needs to be confirmed.

\section{Disease relationships}

Little is known concerning the vector capacity of $H$. impressum. Two strains of Crimean-Congo haemorrhagic fever virus have been isolated from it in Senegal (Hoogstraal 1979), and Dipeolu and Amoo (1984) have recorded the presence of Babesia sp. kinetes in $\mathrm{H}$. impressum in Nigeria.

Acknowledgements. We are grateful to Drs. N.A. Filippova (Zoological Institute, Russian Academy of Sciences, St. Pe- tersburg, Russia), J.H. Oliver, Jr. and L. Beati (US National Tick Collection), J. Dunlop (Natural History Museum of Berlin, Germany), J.B. Walker (South Africa) and Dr. A. Latif and Ms H. Heyne (Gertrud Theiler Tick Museum, Onderstepoort Veterinary Institute, South Africa) for making specimens available for study. We are also indebted to Dr. A. Hall (Laboratory for Microscopy and Analysis, University of Pretoria, South Africa) for his kind help with scanning electron microscopy. Part of this study was undertaken while DAA held a Claude Leon Foundation Postdoctoral Fellowship at the Faculty of Veterinary Science, University of Pretoria. This work was facilitated by a visit to the US National Tick Collection by DAA sponsored by the Integrated Consortium on Ticks and Tick-borne Diseases (ICTTD-3), financed by the International Cooperation Program of the European Union through Coordination Action Project No. 510561. 


\section{REFERENCES}

APANASKEVICH D.A. 2003: Differentiation of closely related species Hyalomma anatolicum and H. excavatum (Acari, Ixodidae) based on a study of all life cycle stages, throughout their entire geographical range. Parazitologiya 37: 259-280. (In Russian.)

APANASKEVICH D.A., HORAK I.G. 2006: The genus Hyalomma Koch, 1844. I. Reinstatement of Hyalomma (Euhyalomma) glabrum Delpy, 1949 (Acari, Ixodidae) as a valid species with a redescription of the adults, the first description of its immature stages and notes on its biology. Onderstepoort J. Vet. Res. 73: 1-12.

CAMICAS J.L. 1970: Contribution a l'étude des tiques du Sénégal (Acarina, Ixodoidea). I. Les larves d'Amblyomma Koch et de Hyalomma Koch. Acarologia 12: 71-102.

Camicas J.L., Hervy J.P., AdAM F., Morel P.C. 1998: The Ticks of the World (Acarida, Ixodida). Nomenclature, Described Stages, Hosts, Distribution. Orstom éditions, Paris, 233 pp.

CENTURIER C. 1982: Contribution to the biology of Hyalomma impressum (Koch, 1844): feeding of Hyalomma impressum larvae on jirds (Meriones unguiculatus). Wiad. Parazytol. 28: 21-25.

DELPY L.P. 1949: Essai critique de synonymie du genre Hyalomma C.L. Koch 1844 depuis Linné, 1758. Ann. Parasitol. Hum. Comp. 24: 464-494.

DiPEOLU O.O., AMOO A. 1984: The presence of kinetes of a Babesia species in the haemolymph smears of engorged Hyalomma ticks in Nigeria. Vet. Parasitol. 17: 41-46.

ElBl A., AnAstos G. 1966: Ixodid ticks of Central Africa. Vol. IV. Genera Aponomma Neumann, 1899, Boophilus Curtice, 1891, Dermacentor Koch, 1844, Haemaphysalis Koch, 1844, Hyalomma Koch, 1844 and Rhipicentor Nuttall and Warburton, 1908. Lists and bibliography. Ann. Mus. R. Afr. Cent., Ser. 8vo, s. Sci. Zool., Tervuren, 184, 412 pp.

FELDMAN-MuHSAM B. 1954: Revision of the genus Hyalomma. I. Description of Koch's types. Bull. Res. Counc. Israel 4: 150 170.

HoogstraAl H. 1956: African Ixodoidea. I. Ticks of the Sudan (with special reference to Equatoria province and with pre- liminary reviews of the genera Boophilus, Margaropus, and Hyalomma). Department of Navy, Washington D.C., 1101 pp.

HoOgSTRAAL H. 1979: The epidemiology of tick-borne CrimeanCongo hemorrhagic fever in Asia, Europe, and Africa. J. Med. Entomol. 15: 307-417.

HoOgStraAl H., KAISER M.N. 1958: The ticks (Ixodoidea) of Egypt: a brief review and keys. J. Egypt. Publ. Health Assoc. 33: 51-85.

KосH C.L. 1844: Systematische Übersicht über die Ordnung der Zecken. Arch. Naturgesch. 10: 217-239.

KOLONIN G.V. 1983: [World distribution of ixodid ticks. Genera Hyalomma, Aponomma, Amblyomma.] Izd. Nauka, Moscow, 120 pp. (In Russian.)

MOREL P.C. 1958: Les tiques des animaux domestiques de 1'Afrique Occidentale Française. Rev. Élev. Méd. Vét. Pays Trop. 11: 153-189.

NEUMANN G. 1901: Revision de la famille des Ixodidés. (4e mémoire). Mém. Soc. Zool. Fr. 14: 249-372.

POMERANTSEV B.I. 1946: [Ticks (fam. Ixodidae) of the USSR and neighbouring countries.] Opred. Faune SSSR Zool. Inst. Akad. Nauk SSSR, Vol. 26. Izd. Akad. Nauk SSSR, Moscow, Leningrad, 28 pp. (In Russian.)

POMERANTSEV B.I. 1950: [Ixodid ticks (Ixodidae).] Fauna SSSR, Paukoobraznye, Vol. 4, No. 2. Izd. Akad. Nauk SSSR, Moscow, Leningrad, 224 pp. (In Russian.)

SCHUlZE P. 1919: Bestimmungstabelle für das Zeckengenus Hyalomma Koch. Sitzungsber. Ges. Naturforsch. Freunde Berl. 5: 189-196.

SCHUlzE P., SCHLOTTKE E. 1930: Bestimmungstabellen für das Zeckengenus Hyalomma Koch s. str. Sitzungsber. Abh. Naturforsch. Ges. Rostock 2: 32-46.

THEILER G. 1962: The Ixodoidea parasites of vertebrates in Africa south of the Sahara (Ethiopian region). Project S 9958. Report to the Director of Veterinary Services, Onderstepoort, $260 \mathrm{pp}$. Mimeographed.

Tonelli Rondelli M. 1930: Ixodoidea del Museo di Milano. Atti Soc. Ital. Sci. Nat. 69: 112-124.

Accepted 30 November 2006 